Infidelity and the Possibility of a Liberal Legal Moralism - forthcoming in Criminal Law and Philosophy Post-print

The final publication is available at Springer via http://dx.doi.org/10.1007/s11572-015-9370-5.

\title{
Infidelity and the Possibility of a Liberal Legal Moralism ${ }^{1}$
}

\author{
Jens Damgaard Thaysen, Ph.D student \\ Aarhus University, School of Business and Social Sciences: Department of Political Science \\ Email: JThaysen@ps.au.dk \\ Address: Bartholins Allé 7 \\ 8000 Aarhus C \\ Denmark \\ Phone: +45 27516750
}

\begin{abstract}
This paper argues that according to the influential version of legal moralism presented by Moore infidelity should all-things-considered be criminalized. This is interesting because criminalizing infidelity is bound to be highly controversial and because Moore's legal moralism is a prime example of a self-consciously liberal legal moralism, which aims to yield legislative implications that are quite similar to liberalism, while maintaining that morality as such should be legally enforced. Moore tries to make his theory yield such implications, first by claiming that the scope of our moral obligations is much more limited than legal moralists have traditionally claimed, and second by allowing for the possibility that the goodness of legally enforcing morality is often outweighed by the badness of limiting citizens' morally valuable autonomy and spending scarce resources on enforcement. If Moore is successful in this, legal moralism is strengthened because it becomes immune to many of the most damaging liberal objections. By showing that despite making those moves Moore's legal moralism is still committed to criminalizing infidelity, a manifestly illiberal implication for legislation, it is established that Moore is unsuccessful in creating a liberal legal moralism, and Moore's failure in this regard raises questions about whether there can be such a thing as a liberal legal moralism.
\end{abstract}

Legal moralism and liberalism are two influential theories of what conduct ought to be criminal.

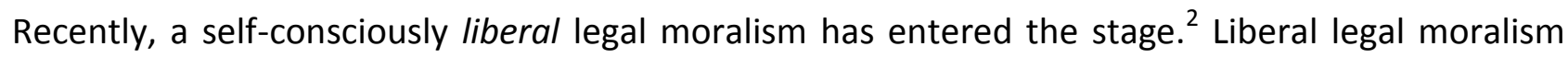

\footnotetext{
${ }^{1}$ I am very grateful to Andreas Brøgger Albertsen, David Vestergaard Axelsen, Morten Brænder, Kristian Kriegbaum Jensen, Kasper Lippert-Rasmussen, Peter Damgaard Marschall, Søren Flinch Midtgaard, Per Mouritsen, Lasse Nielsen, Tore Vincents Olsen, Lars Petrat-Meyer, and an anonymous reviewer for their insightful and useful comments.

${ }^{2}$ Cf. Michael S. Moore, Placing Blame: A Theory of the Criminal Law, first published in paperback (Oxford: Oxford University Press, 1997); Gerald Dworkin, "Devlin Was Right: Law and the Enforcement of Morality," William and Mary Law Review 40, no. 3 (1999): 927-946. While Richard Arneson does not explicitly endorse legal moralism, his writing
} 
Infidelity and the Possibility of a Liberal Legal Moralism - forthcoming in Criminal Law and Philosophy Post-print

The final publication is available at Springer via http://dx.doi.org/10.1007/s11572-015-9370-5.

retains the core claim of classical legal moralism that morality as such ${ }^{3}$ should be legally enforced, while having implications for legislation that are closer to liberalism than to classical legal moralism. ${ }^{4}$ In this paper, I argue that according to Michael Moore's influential version of this theory infidelity should be criminalized, and thus one should either embrace the criminalization of infidelity or accept that Moore's theory is in need of revision. Regardless of which alternative one embraces the case of infidelity raises some questions about the possibility of liberal legal moralism.

First, I examine Moore's liberal legal moralism. Second, I justify assuming that infidelity is morally wrong. Third, I discuss whether any reasons against criminalizing what is morally wrong can outweigh the reason in favour of criminalizing infidelity because it is morally wrong. Fourth, I make some concluding remarks regarding the possibility of liberal legal moralism.

\section{Moore's Liberal Legal Moralism}

I focus on the seminal version of legal moralism defended by Michael Moore. I share this focus with prominent contemporary critics of legal moralism, such as Antony Duff and Douglas Husak. ${ }^{5}$

Legal moralism is a theory of criminal legislation which seeks to tell us what conduct ought to be criminal. ${ }^{6}$ Moore derives his legal moralist theory of criminal legislation from his retributivist theory of the proper aim of punishment, according to which it is intrinsically valuable that those who commit moral wrongs are punished. ${ }^{7}$ For Moore the aim of criminal legislation is to realize this value by instituting punishment for (i.e., criminalizing) all moral wrongs and only moral wrongs. ${ }^{8}$ Legal moralism is both a theory of the proper legislative motivation according to which

\footnotetext{
also seems to point towards a liberal legal moralism; see "The Enforcement of Morals Revisited," Criminal Law and Philosophy 7, no. 3 (October 2013): 435-454.

${ }^{3}$ By "morality as such" I mean all of morality as opposed to a specific part of morality (e.g., moral prohibitions against harming others).

${ }^{4}$ For classical legal moralism, see: James Fitzjames Stephen, Liberty, Equality, Fraternity, Primary Source Edition (New York: Holt \& Williams, 1878); Patrick Devlin, The Enforcement of Morals (Indianapolis: Liberty Fund, 2009); Robert P George, Making Men Moral: Civil Liberties and Public Morality (New York: Clarendon Press; Oxford University Press, 1993).

${ }^{5}$ Antony Duff, Answering for Crime: Responsibility and Liability in the Criminal Law, Legal Theory Today (Oxford ; Portland, Oregon: Hart Pub, 2007), 47, 84ff; Douglas N. Husak, Overcriminalization: The Limits of the Criminal Law (New York: Oxford University Press, 2008), 196ff.

${ }^{6}$ Michael S. Moore, “A Tale of Two Theories," Criminal Justice Ethics 28, no. 1 (May 2009): 31.

${ }^{7}$ Moore, Placing Blame, $153 \mathrm{ff}$.

${ }^{8}$ Ibid., 662. See also pp. 80 \& 645.
} 
Infidelity and the Possibility of a Liberal Legal Moralism - forthcoming in Criminal Law and Philosophy Post-print

The final publication is available at Springer via http://dx.doi.org/10.1007/s11572-015-9370-5.

the only proper motivation of criminal legislation is the "prevention and punishment of wrongdoing" $^{\prime 9}$ (Moore seems especially keen on emphasizing that his legal moralism does not permit legislation to be motivated by the paternalist concerns about bettering the criminal ${ }^{10}$ ) and a criterion of justified legislation which demands that the criminalized conduct is in fact morally wrong (i.e., that the properly motivated legislator is not mistaken about the moral wrongness of the criminalized conduct). ${ }^{11}$

Thus, according to Moore's legal moralism all moral wrongs and only moral wrongs should be criminalized because, and only because, they are immoral. Prima facie, this sounds overinclusive. Surely minor moral wrongs like cutting in line at a queue in the supermarket should not be criminalized. Fortunately, this is not what Moore believes. Moore employs a balancingmodel where a certain conduct should be criminalized if, and only if, the reasons in favour of criminalization outweigh the reasons against criminalization. ${ }^{12}$ Moore's claim that all moral wrongs should be criminalized is best understood as the claim that there is always and only a pro tanto reason in favour of criminalizing what is morally wrong. The strength of this reason in favour of criminalizing any particular moral wrong, $\mathrm{X}$, is directly proportional to the desert of those who do $\mathrm{X}$. The desert of those who do $\mathrm{X}$ is in turn a product of the degree to which $\mathrm{X}$ is morally wrong, and the moral culpability with which they $\operatorname{did} X{ }^{13}$

\section{Liberal Legal Moralism: Means and Ends}

Moore frequently emphasizes that his legal moralism is a liberal legal moralism, ${ }^{14}$ which is "quite liberal-in-outcome, if not liberal-in-form." ${ }^{15}$ I take this to mean that, while liberalism and Moore's legal moralism are incompatible intensionally, Moore's legal moralism and liberalism have quite

\footnotetext{
${ }^{9}$ Michael S. Moore, "Liberty's Constraints on What Should Be Made Criminal," in Criminalization: The Political Morality of the Criminal Law, ed. R. A. Duff, et al., Criminalization Series 4 (New York, NY: Oxford University, 2014 ), 195.

${ }^{10}$ Moore, Placing Blame, 758; Moore, “Liberty's Constraints on What Should Be Made Criminal," 194, 195; Moore, “A Tale of Two Theories," 33.

${ }^{11}$ Moore, "Liberty's Constraints on What Should Be Made Criminal," 195.

12 Moore, Placing Blame, 659-660 \& 739ff. For a critique of the balancing-model, see Jonathan Schonsheck, On Criminalization: An Essay in the Philosophy of the Criminal Law, Law and Philosophy Library, v. 19 (Dordrecht; Boston: Kluwer Academic Publishers, 1994), 29-101.

${ }^{13}$ Moore, Placing Blame, 71.

${ }^{14}$ Ibid., 80, 640, 661-665, 741, 756-757; Moore, “A Tale of Two Theories," 33, 38, 41.

${ }^{15}$ Moore, Placing Blame, 661.
} 
Infidelity and the Possibility of a Liberal Legal Moralism - forthcoming in Criminal Law and Philosophy Post-print

The final publication is available at Springer via http://dx.doi.org/10.1007/s11572-015-9370-5.

similar implications for which legislation is justified. ${ }^{16}$ Moore mentions only three criminal prohibitions which are justified according to his version of legal moralism, but not according to liberalism: prohibitions against cruelty to animals, mutilation of dead bodies and the extinction of a species. ${ }^{17}$ Moore must hold these differences between the legislative implications of his version of legal moralism and liberalism to be relatively unimportant compared to the differences between liberalism and classical legal moralism, which is not quite liberal-in-outcome. Moore writes:

What makes him [the liberal legal moralist] a liberal is how he comes out at the end of the day assessing the rightness of laws dealing with homosexuality, abortion and the like. ${ }^{18}$

But what makes criminalizing cruelty to animals, the mutilation of dead bodies and the extinction of a species compatible with being quite liberal-in-outcome, while criminalizing homosexuality is not? I suggest that a legal moralist theory, $\mathrm{LM}_{1}$, is liberal when the legislation which is justified according to $\mathrm{LM}_{1}$ but not according to liberalism, would not be regarded as obviously and pretheoretically unjust by liberals. For instance, the reasons any given liberal will give for not being a legal moralist are far more likely to be opposition to the criminalization of conduct, such as homosexuality than opposition to criminalizing the mutilation of dead bodies, even if the latter is also regarded as being incompatible with liberalism. If I am right in this, liberal legal moralism should be understood as a version of legal moralism, which has rather few legislative implications not shared by liberalism, and when the implications do differ, they only differ in the case of relatively uncontroversial laws.

Moore uses two strategies to make his legal moralism more liberal-in-outcome. First, he suggests that the scope of our moral obligations is far more limited than assumed by classical legal moralists. ${ }^{19}$ Second, Moore presents a number of reasons against criminalizing what is

\footnotetext{
${ }^{16}$ Moore explicitly claims that the implications of his legal moralism "make little to no difference in what can be justifiably criminalized" compared to Husak's liberal theory of criminalization. (Moore, "A Tale of Two Theories," 38; cf. Husak, Overcriminalization.)

${ }^{17}$ Moore, Placing Blame, 646. See also Moore, "A Tale of Two Theories," 39. Moore does not claim that this list is exhaustive.

${ }^{18}$ Moore, Placing Blame, 661.

${ }^{19}$ Ibid., 662.
} 
Infidelity and the Possibility of a Liberal Legal Moralism - forthcoming in Criminal Law and Philosophy Post-print

The final publication is available at Springer via http://dx.doi.org/10.1007/s11572-015-9370-5.

morally wrong. First, when there is reasonable doubt about whether a given behaviour is truly morally wrong, this should count against legislating. ${ }^{20}$ Second, legislation should be "clear, public, consistent, prospective, [and] general." ${ }^{21}$ Some moral wrongs may not be possible to criminalize through a clear, public, consistent and general law, which is a strong reason against criminalizing those wrongs. Third, there needs to be a fair opportunity to avoid choosing to do wrong. If the wrongdoer did not have a fair opportunity to act differently from what she did, she is not truly culpable. $^{22}$ Fourth, criminalizing conduct always infringes on negative liberty; ${ }^{23}$ according to Moore, negative liberty is instrumentally valuable as a means to a number of intrinsically valuable goods. ${ }^{24}$ These goods are positive liberty, Millian autonomy, Kantian autonomy and "the simple psychological truth that people generally prefer to make their own decisions free of coercion." ${ }^{25}$ Thus, the value of these goods count as reasons against criminalizing what is morally wrong. ${ }^{26}$ Fifth, enforcing criminal bans on what is morally wrong may be costly both in resources and in other values, which counts as another reason against criminalizing. ${ }^{27}$ These reasons against criminalizing what is morally wrong should be weighed against, and may occasionally outweigh, the reason in favour of criminalizing what is morally wrong.

It is desirable for legal moralism to be liberal. Liberal legal moralism is less vulnerable to liberal attacks that it has counter-intuitive implications for legislation, which are not shared by liberalism, simply because it has fewer implications which are not shared by liberalism, and none of those differing implications are highly salient in the way, say, anti-gay legislation is. My aim in this paper is to show that Moore's legal moralism implies that there is an all-things-considered sufficient reason to criminalize infidelity. I argue that Moore mentions no reasons against criminalizing what is morally wrong which can protect infidelity from criminalization. Thus, Moore's second strategy for making his legal moralism liberal-in-outcome fails to protect infidelity

\footnotetext{
${ }^{20}$ Ibid.

${ }^{21}$ Moore, Placing Blame, 660.

22 Ibid., 746.

${ }^{23}$ Moore, “Liberty's Constraints on What Should Be Made Criminal," 185.

${ }^{24}$ Ibid., 186-188.

${ }^{25}$ Ibid., 188.

${ }^{26}$ Ibid., $200 f f$.

${ }^{27}$ Moore, Placing Blame, 663. In his recent work, Moore lists saving the costs of enforcement as the fifth good to which negative liberty is instrumentally valuable. (Moore, "Liberty's Constraints on What Should Be Made Criminal," 188.) This grouping of the costs of enforcement together with the four values mentioned above seems odd for two reasons. First, this good is itself instrumental, unlike the four other goods. Second, unlike the other values, it is not those who engage in the conduct that might be criminalized that benefit primarily from saving the costs of enforcement. For this reason, I discuss the costs of enforcement separately.
} 
Infidelity and the Possibility of a Liberal Legal Moralism - forthcoming in Criminal Law and Philosophy Post-print

The final publication is available at Springer via http://dx.doi.org/10.1007/s11572-015-9370-5.

from criminalization. If infidelity is morally wrong, the first strategy also fails. If so, neither of Moore's two general strategies aimed at making his legal moralism liberal-in-outcome protect infidelity from criminalization. Criminalizing infidelity is something which at least some liberals would regard as obviously and pre-theoretically unjust, as Duff writes:

[B]y asking why it should seem so obvious that it [adultery] should not be criminal, we may become clearer about what can constitute a proper ground for criminalization. $^{28}$

Note how Duff stresses the pre-theoretical nature of the conviction. For Duff the conviction that infidelity should not be criminalized is not a theoretically derived judgment, but rather a judgment on the basis of which to derive a theory. This indicates that a version of legal moralism which has the implication that infidelity should be criminalized is not liberal. Because Moore's defence of legal moralism is unparalleled in its detail and sophistication, and because of his commitment to demonstrating his version of legal moralism to be quite liberal-in-outcome, this raises doubts about the very possibility of liberal legal moralism.

All of this remains to be argued. In this section, I merely hope to convince the reader that at least one of the following propositions must be true:

1) Infidelity is not morally wrong.

2) The reason in favour of criminalizing infidelity is outweighed by one or more reasons against criminalizing infidelity.

3) Moore's legal moralism should be revised.

4) Infidelity should be criminalized.

I do not argue at length that 1 ) is false, but will provide some reasons to believe this is so in the next section. I devote the greater part of this paper to showing that 2) is false. When discussing 2) I only discuss the reasons against criminalizing what is morally wrong explicitly mentioned by

\footnotetext{
${ }^{28}$ Duff, Answering for Crime, 145.
} 
Infidelity and the Possibility of a Liberal Legal Moralism - forthcoming in Criminal Law and Philosophy Post-print

The final publication is available at Springer via http://dx.doi.org/10.1007/s11572-015-9370-5.

Moore. ${ }^{29}$ There may be some other value, unmentioned by Moore, which allows him to deny that infidelity should be criminalized, while remaining true to his theory. However, it is unclear what that value should be. If 1) and 2) are false, then either 3) or 4) must be true. I do not argue here, whether 3) or 4) (or both) should be accepted. Both propositions seem interesting enough. Importantly, in this paper, I do not argue that infidelity should not be criminalized. Rather the argument is that either 3 ) or 4) must be true, and therefore either Moore's legal moralism should be revised, or infidelity should be criminalized. I assume the former is interesting enough in itself, while accepting the latter will show that Moore's legal moralism is not quite liberal-in-outcome at all, which is also interesting. I now move on to discuss 1 ).

\section{The Assumption of the Moral Wrongfulness of Infidelity}

An obvious way to deny that Moore's legal moralism implies that infidelity should be criminalized is to deny that infidelity is morally wrong. This corresponds to the first strategy for making legal moralism liberal. In this section, I provide some reasons for assuming that infidelity is normally morally wrong. A commits infidelity when:

A has sexual relations with $C$, while $A$ is in a committed romantic relationship with $B$, and $B$ does not consent to the sexual relationship between $A$ and $C .^{30}$

The reason A cannot commit infidelity when B consents is that otherwise the definition of infidelity would include partners in open relationships and those who engage in various alternative sexual lifestyles. Here we are only concerned with whether A does something morally wrong. Whether $\mathrm{C}$ also does something morally wrong is of no interest. There are several reasons for believing that infidelity is normally morally wrong. Infidelity often involves the breach of an explicit

\footnotetext{
${ }^{29}$ I draw primarily on the following works by Moore: "Liberty's Constraints on What Should Be Made Criminal"; Placing Blame; "A Tale of Two Theories."

${ }^{30}$ Infidelity can also occur in polyamorous relationships; in those cases the definition should be revised by adding more romantic partners than $B(E, D, F$, etc.), where at least one of them, does not consent to the sexual relationship between $A$ and $C$. Throughout, I shall write as if this paper only concerned traditional monogamous relationships, but what I say about infidelity is intended to equally apply to polyamorous relationships.
} 
Infidelity and the Possibility of a Liberal Legal Moralism - forthcoming in Criminal Law and Philosophy Post-print

The final publication is available at Springer via http://dx.doi.org/10.1007/s11572-015-9370-5.

or implicit promise. ${ }^{31}$ Even if no such promise has been made, infidelity is likely to knowably and foreseeably be a severely hurtful experience for the deceived partner. Infidelity commonly gives rise to feelings of shame, undesirability and inadequacy, ${ }^{32}$ and even symptoms akin to posttraumatic stress disorder. ${ }^{33}$ People invest time and effort in their relationships and in the worst cases infidelity can undermine a life-long project. Belief in the fidelity of one's partner can form part of the basis of potentially life-changing decisions, such as where to live and where to work. The fact that infidelity is the most common cause of divorce across 160 different cultures ${ }^{34}$ can be taken as evidence that infidelity is normally viewed as unacceptable behaviour by the deceived partner. I do not claim that any of these reasons are singly sufficient to make infidelity morally wrong. But it is reasonable to assume that infidelity is normally morally wrongful for one or several of these reasons.

A critic might object to the assumption by claiming that Moore explicitly denies that infidelity can be morally wrong. Moore writes:

On my view of sex, for example, morality by and large does not concern itself with much of what passes for social mores in our society on the topic sex. I think that it trivializes morality to think that it obligates us about what organ we insert into what orifice of what gender of what species. ${ }^{35}$

Since infidelity is a sexual act, the critic could object that Moore denies that infidelity is morally wrong because sexual acts cannot be morally wrong. However, Moore cannot hold this view, since it is deeply implausible. Just think of the grave moral wrong of rape. A far more plausible interpretation is that according to Moore an act cannot be morally wrong solely in virtue of being

\footnotetext{
${ }^{31}$ Richard J. Bischoff, “Infidelity: The Implications of Current Research for Couple Therapy," Journal of Couple \& Relationship Therapy 2, no. 4 (October 21, 2003): 73-78.

${ }^{32}$ Katherine M. Hertlein, Joseph L. Wetchler, and Fred P. Piercy, "Infidelity: An Overview," Journal of Couple \& Relationship Therapy 4, no. 2-3 (September 13, 2005): 5-16; Shackelford, LeBlanc, and Drass, "Emotional Reactions to Infidelity", Cognition \& Emotion 14, no. 5 (September, 2000): 643-659; Richard J. Bischoff, "Infidelity: The Implications of Current Research for Couple Therapy," Journal of Couple \& Relationship Therapy 2, no. 4 (October 21, 2003): 73-78. ${ }^{33}$ Dennis C. Ortman, "Post-Infidelity Stress Disorder," Journal of Psychosocial Nursing \& Mental Health Services 43, no. 10 (2005): 46-54; Don-David Lusterman, "Marital Infidelity: The Effects of Delayed Traumatic Reaction," Journal of Couple \& Relationship Therapy 4, no. 2-3 (September 13, 2005): 71-81; Olivia Leeker and Al Carlozzi, "Effects of Sex, Sexual Orientation, Infidelity Expectations, and Love on Distress Related to Emotional and Sexual Infidelity," Journal of Marital and Family Therapy 40, no. 1 (January 2014): 68-91.

${ }^{34}$ Shackelford, LeBlanc, and Drass, "Emotional Reactions to Infidelity."

${ }^{35}$ Moore, Placing Blame, 756.
} 
Infidelity and the Possibility of a Liberal Legal Moralism - forthcoming in Criminal Law and Philosophy Post-print

The final publication is available at Springer via http://dx.doi.org/10.1007/s11572-015-9370-5.

a certain kind of sexual act. For instance, the coercion and violence involved in rape presumably play a key role in making rape severely morally wrong. Likewise, the wrongfulness of infidelity does not consist solely in being a certain kind of sexual act, but rather in either the known and foreseen consequences of infidelity or the breach of a deontological rule (against something else than certain kinds of sexual acts). Thus, it is reasonable to assume that infidelity is normally morally wrong, though I have provided no conclusive argument.

\section{How Wrongful is Infidelity?}

Since the case in favour of criminalizing infidelity is to be weighed against the reasons not to criminalize infidelity, it becomes important to know how seriously wrongful infidelity is, and whether we can formulate a law that criminalizes the (sufficiently) wrongful instances of infidelity, without criminalizing instances of infidelity that are not (sufficiently) wrongful. Infidelity may be like suicide which is sometimes seriously wrongful, ${ }^{36}$ but sometimes not and the factors determining its wrongfulness are too many and varied to incorporate in a law. ${ }^{37}$ However, it seems that this is not so, and that it is possible to formulate a law that only captures (sufficiently) wrongful instances of infidelity through a specification of what is meant by "committed romantic relationship."

This is because, assuming infidelity is wrong, the features that make it morally wrong are almost certain to increase in strength proportionally to the length of the romantic relationship, and so does the degree to which we can be certain of the wrongfulness of infidelity in the first place. First, the longer A and $B$ have been romantically involved, the greater the chance that they have either clearly established that B consents to $A$ having sexual relations with $C$, thus making $A^{\prime}$ s infidelity fall outside the definition of criminal infidelity, or that B does not consent to such relations, thus making infidelity the breach of an explicit promise. Second, the longer $A$ and $B$ have been romantically involved, the more likely and the more certain it is that A's infidelity will severely hurt B. Ceteris paribus being deceived by your boyfriend of 30 days is less hurtful than being deceived by your husband of 30 years. Third, it is trivially true, that the longer the duration of a romantic relationship, the more time has been invested in the relationship. If nothing else

\footnotetext{
${ }^{36}$ Cf. Ibid., 791-792.

${ }^{37}$ I thank an anonymous reviewer for suggesting this possibility and providing the example.
} 
Infidelity and the Possibility of a Liberal Legal Moralism - forthcoming in Criminal Law and Philosophy Post-print

The final publication is available at Springer via http://dx.doi.org/10.1007/s11572-015-9370-5.

there is a "romantic opportunity cost" of being in the relationship which is directly proportional to the investment of time in a romantic relationship, since this time could have been spent building a life with a faithful partner. Furthermore, the longer the duration of a romantic relationship, the greater the chance that B has based life-changing decisions on her belief in A's fidelity, such as turning down otherwise attractive job offers because the job is too far away from A's work, or refrained from moving to an otherwise attractive location because it is too far away from A's residence.

Thus, both the severity of the wrong-making features of infidelity and the certainty with which we can know they are present will uniformly rise with the duration of a romantic relationship. Therefore, for the purposes of a hypothetical statue criminalizing infidelity, whether a romantic relationship is committed is determined in part by the duration of the romantic relationship. Because of the relation between the wrong-making features of infidelity and the duration of a romantic relation, it will be possible to specify a duration of a romantic relationship beyond which we can reasonably assume that infidelity is always ${ }^{38}$ quite seriously morally wrong. I have no certain answer to what the relevant duration is, but for purposes of illustration assume that a romantic relationship is committed, when $A$ and $B$ have been romantically involved for at least three years. This concludes my discussion of the immorality of infidelity. I now move on to discuss the reasons against criminalizing what is morally wrong in relation to infidelity.

\section{Reasons Not to Criminalize Infidelity}

In this section, I discuss whether any reason not to criminalize what is morally wrong outlined by Moore outweighs the reason to criminalize infidelity. I argue that they do not. Thus, if we accept Moore's legal moralism, there is an all-things-considered sufficient reason to criminalize infidelity. I group Moore's reasons for not criminalizing what is morally wrong into two major categories: negative liberty and costs of enforcement. If the strength of these reasons against criminalizing what is morally wrong were invariable between different moral wrongs, assessing whether they could outweigh the reasons in favour of criminalizing infidelity would simply be a matter of how seriously wrong infidelity is. However, the strength of these reasons against criminalizing what is

\footnotetext{
${ }^{38}$ Though it, of course, admits of various forms of defence.
} 
Infidelity and the Possibility of a Liberal Legal Moralism - forthcoming in Criminal Law and Philosophy Post-print

The final publication is available at Springer via http://dx.doi.org/10.1007/s11572-015-9370-5.

morally wrong does vary between different moral wrongs ${ }^{39}$ and needs to be discussed at length in relation the moral wrong of infidelity. Before moving on to discuss those, I will briefly dispense with three of Moore's suggestions, which are not discussed at length.

First, Moore suggests that, if there is doubt over what is morally required, this doubt should be resolved in favour of not legislating. ${ }^{40}$ Since I have assumed that infidelity is morally wrong, and argued that when the unfaithful partner has been in a relationship with the deceived partner for a certain period, we can be relatively certain that it is quite seriously morally wrong, I do not discuss this limit of the law. Second, Moore highlights that laws should be "clear, public, consistent, prospective [and] general ..." ${ }^{\prime 41}$ Clearly, legislation against infidelity is capable of being prospective and public. ${ }^{42}$ I discussed above, whether we can find clear, consistent, and general criteria for when infidelity is (sufficiently) morally wrong. I argued that we can use the length of the romantic relationship as such a clear, consistent and general criterion. Third, regarding the requirement of fair opportunity to avoid doing wrong, having sexual intercourse is normally a conscious act, which we have a fair opportunity of not doing. Thus, this requirement provides no reason against criminalizing infidelity. I now move on to discuss the value of negative liberty.

\section{Negative Liberty}

According to Moore, the value of negative liberty does much of the work in justifying why some moral wrongs should not be criminalized. Negative liberty is instrumentally valuable as a means to a number of more fundamentally valuable goods. ${ }^{43}$ These are positive liberty, Kantian autonomy, Millian autonomy, and the desire for free choice. Before moving on to the more complicated discussions of Kantian and Millian autonomy, I briefly discuss whether the value of positive liberty and the desire for free choice can provide a reason against criminalizing infidelity, which can outweigh the reason in favour of criminalizing infidelity.

\footnotetext{
${ }^{39}$ Moore, “Liberty's Constraints on What Should Be Made Criminal," 201.

${ }^{40}$ Moore, Placing Blame, 662.

${ }^{41}$ Ibid., 660.

${ }^{42}$ I take it that a law is public when the existence of the law is publicly announced, and information about the requirement of the law is publicly available.

${ }^{43}$ Moore, "Liberty's Constraints on What Should Be Made Criminal," 186-188.
} 
Infidelity and the Possibility of a Liberal Legal Moralism - forthcoming in Criminal Law and Philosophy

Post-print

The final publication is available at Springer via http://dx.doi.org/10.1007/s11572-015-9370-5.

\section{Positive Liberty and the Desire for Free Choice}

Positive liberty to $X$ is the ability to $X$. Negative liberty to do $X$ is a necessary condition of positive liberty to do X. According to Moore, positive liberty is a good. ${ }^{44}$ When discussing whether the value of positive liberty can give us a reason not to criminalize infidelity which outweighs the positive reason to criminalize infidelity, we must ignore the instrumental value of positive liberty as a means to be the author of one's own life, since this conflates the value of positive liberty with the value of Millian autonomy, which is discussed later. Not all criminal laws take an equal amount of positive liberty. They differ on two dimensions. First, criminal laws that make positive requirements (e.g., Good Samaritan laws) take more positive liberty than criminal laws that make negative requirements. Since persons cannot usually do multiple things at once, legally requiring persons to do $X$ deprives them of the positive liberty to do all other actions. ${ }^{45}$ Second, negative requirements also vary in how much positive liberty they take. ${ }^{46}$ Moore compares prohibiting citizens from exiting their homes with prohibiting murder. I take the deeper point to be that the negative liberty to do $X$ is sometimes a precondition for the positive liberty to do a host of other things (the negative liberty to leave one's house is a necessary condition of having the positive liberty to play soccer, go to Venice, etc.), while at other times the negative liberty to do $X$ is hardly a necessary condition of having a positive liberty to anything other than $X$ is itself (the negative liberty to commit murder is unnecessary for the positive liberty do many more things than commit murder). ${ }^{47}$ Plainly, criminalizing infidelity is making a negative legal requirement. Furthermore, the negative liberty to commit infidelity is unnecessary for the positive liberty to do much more than actually committing infidelity. Since a ban on infidelity is not a ban on fornication in general, the legality of infidelity is unnecessary for the positive liberty of $A$ to have sexual relations with $C$. $A$ still has the positive liberty to have sex with $\mathrm{C}$, provided he terminates her romantic relationship with $B$ first. The negative liberty to commit infidelity is only a necessary condition of A's positive liberty to have sexual relations with $\mathrm{C}$ while being in a committed romantic relationship with $\mathrm{B}$.

\footnotetext{
${ }^{44}$ Ibid., 186.

${ }^{45}$ Ibid., 201.

${ }^{46}$ Ibid. So does positive requirements, but since criminalizing infidelity is obviously making a negative requirement I do not discuss this.

${ }^{47}$ This seems to me to be what Joel Feinberg covered be his distinction between "limited" and "fecund" options (Feinberg, Harm to Others, 208.)
} 
Infidelity and the Possibility of a Liberal Legal Moralism - forthcoming in Criminal Law and Philosophy Post-print

The final publication is available at Springer via http://dx.doi.org/10.1007/s11572-015-9370-5.

Though criminalizing infidelity limits positive liberty, I think these considerations show that it does not limit positive liberty to any particularly great extent, and consequently the value of positive liberty does not provide a very weighty reason against criminalizing infidelity which is alone sufficient to outweigh the reason in favour of criminalizing infidelity, though it is possible that it is one of a number of reasons that are jointly sufficient.

The desire for free choice is somewhat tricky since its application to the criminalization of infidelity relies on some empirical claims about people's preferences. I do not know whether people strongly desire freedom to choose whether to be faithful to their partners, but at any rate Moore treats this requirement as only having the potential to provide a reason that could outweigh the positive reasons to criminalize minor wrongs. ${ }^{48}$ I have attempted to justify the assumption that infidelity is more seriously morally wrongful than that. If that is correct, then people's desire for free choice cannot outweigh the positive reason to criminalize infidelity. I now move on to discuss the value of Kantian autonomy.

\section{Kantian Autonomy}

By the value of Kantian autonomy, Moore refers to the value of making the right choice because it is the right choice (i.e., acting autonomously in a Kantian sense ${ }^{49}$ ) instead of for some other reason, like fear of legal punishment. Moore claims that the enactment of criminal legislation causes a loss in this value because it makes it less likely that agents do the right thing for the right reason. Moore writes:

[I]f there is value in acting for the right reasons, it is easy to see how legal coercion can prevent the attainment of that value, for the avoidance of legal sanctions can easily supplant the more virtuous motivations for an action that might otherwise have moved an agent to act. $^{50}$

\footnotetext{
${ }^{48}$ Moore, "Liberty's Constraints on What Should Be Made Criminal," 200-202.

${ }^{49}$ Immanuel Kant, Critique of Practical Reason (Mineola, NY: Dover Publications, 2004), 34.

${ }^{50}$ Moore, "Liberty's Constraints on What Should Be Made Criminal," 187-188. See also Moore, Placing Blame, 748.
} 
Infidelity and the Possibility of a Liberal Legal Moralism - forthcoming in Criminal Law and Philosophy Post-print

The final publication is available at Springer via http://dx.doi.org/10.1007/s11572-015-9370-5.

The bad of making people act for the wrong reasons must come about through the effect of legislation on those who were going to do the right thing for the right reason before legislation, and who will either do the right thing for the wrong reason (fear of legal punishment) or do the wrong thing after legislation has been passed. Otherwise criminalizing wrongful behaviour would prevent no autonomously chosen rightful behaviour. Thus, for this consideration to be relevant at least one person who was going to do the right thing for the right reason before legislation was passed, must change her reasons so that she now only does the right thing out of fear of legal punishment, or does not do the right thing at all.

However, those who were going to do the right thing when no legislation against wrongdoing was in place must have held themselves to have a sufficient reason to do the right thing independently of any legislation. Herein lays the problem. Suppose that the threat of legal punishment is a sufficient reason to refrain from doing what is morally wrong. It is hard to see how the addition of a new sufficient reason (fear of legal punishment) to a set of reasons which the actor already held to be sufficient for acting (it is the right thing to do) changes the reasons for which the actor does the right thing. It is even harder to see how the addition of a new sufficient reason to a set of reasons for action, which the actor already held to be sufficient for action, can result in the actor not doing the action. This supposes that people are rational, which they are sometimes not, but even then, should we expect irrational behaviour of this sort to be common $?^{51}$ Perhaps this is too uncharitable an interpretation of Moore's point. Maybe Moore is referring to the long term effects of the law on the motivation to do the right thing. On this interpretation criminalizing what is morally wrong does not make people less likely to do the right thing for the right reason by changing their already formed motives. Rather it affects what motives they form to begin with. ${ }^{52}$ Suppose the child, A, has not yet formed any intention not to commit infidelity. If infidelity is not criminalized, he will grow up to form an intention never to commit infidelity because of the moral wrongness of infidelity. If infidelity is criminalized, he will also form an intention never to commit infidelity, but only out of fear of legal punishment. This avoids the problems discussed above. This version of the claim that criminalizing what is morally wrong carries a cost to Kantian autonomy relies on some empirical assumptions about the effects of the law on the formation of motives. The exact opposite claim-that the law in a just legal system

\footnotetext{
${ }^{51}$ For a somewhat similar point, see Heidi M. Hurd, "Liberty in Law," Law and Philosophy 21, no. 4-5 (2002): 415.

52 I thank an anonymous reviewer for suggesting this possibility.
} 
Infidelity and the Possibility of a Liberal Legal Moralism - forthcoming in Criminal Law and Philosophy Post-print

The final publication is available at Springer via http://dx.doi.org/10.1007/s11572-015-9370-5.

facilities the formation of the right reasons for doing the right thing, because it reliably marks out moral wrongs-seems just as plausible. Such a claim is made by John Rawls in his principles of moral psychology, where he writes that the institutions of a just society help persons acquire a sense of justice themselves. Here laws do not supplant the right reasons to do the right thing, rather they are crucial in facilitating a child's transition from acting morally because of fear of being punished (by her parents) and because of her friendly feeling towards others to acting morally out of a sense of justice ${ }^{53}$ - which I take to be the virtuous motive. Of course, this is merely stating the opposing case, ${ }^{54}$ but if nothing else Moore is relying on some controversial empirical claims about the law's effect on the formation of motives to do the right thing, which are not any more intuitively appealing than the opposing claims.

Suppose arguendo that Moore's empirical assumptions about the motivational effects of the law are correct and the opposing claims have nothing to them. As Moore writes, "Kantian autonomy will by itself protect wrongful actions from criminalization wherever it is more important that an act be done for the right reason than it be done rightly." ${ }^{55}$ It is still doubtful whether the value of Kantian autonomy provides a very weighty reason against criminalizing infidelity. Of course most of us would prefer that our romantic partner refrained from being unfaithful out of feelings of love and loyalty rather than fear of legal punishment. However, avoiding the intense negative feelings associated with having an unfaithful partner and the keeping of the implicit or explicit promise of fidelity seems to have considerable value independently of the motives a given romantic partner has for abstaining from infidelity. ${ }^{56}$ I do not dispute that autonomously chosen rightful behaviour is valuable, but I am sceptical that criminalizing what is morally wrong endangers this value to any great extent. Even if I am wrong

\footnotetext{
53 John Rawls, A Theory of Justice, Original edition (Cambridge, Mass: Belknap Press, 2005), Chapter VIII. Particularly $\S \S 72,75$. See also John Rawls, Political Liberalism, Expanded edition, Columbia Classics in Philosophy (New York: Columbia University Press, 2005), 85-86.

${ }^{54}$ For another philosopher making the opposing case, see John Stuart Mill, On Liberty and Utilitarianism, Everyman's Library 81 (New York: Knopf: Distributed by Random House, 1992), 61. For a supporter of Moore's claim see Joseph Raz, when he writes that the role of authoritative instructions is "to enable people to act on non-ultimate reasons. It is to save them the need to refer to the very foundations of morality." (Joseph Raz, "Authority and Justification," Philosophy \& Public Affairs 14, no. 1 (1985): 26.) While Moore would presumably disagree with Raz that this effect of law is desirable, his remarks on Kantian autonomy rely on an agreement with Raz that laws can in fact have this effect. ${ }^{55}$ Moore, "Liberty's Constraints on What Should Be Made Criminal," 202.

${ }^{56}$ Moore explicitly mentions our duties to keep our promises as an example of a moral duty, where it is more important that it is done, than that it is done for the right reason (Ibid.)
} 
Infidelity and the Possibility of a Liberal Legal Moralism - forthcoming in Criminal Law and Philosophy

Post-print

The final publication is available at Springer via http://dx.doi.org/10.1007/s11572-015-9370-5.

about this, it is doubtful that the value of Kantian autonomy outweighs the reason in favour of criminalizing infidelity. I now proceed to discuss Millian autonomy.

\section{Millian Autonomy}

According to Moore, Millian autonomy concerns the authorship of the individual over her own actions. Moore helpfully fleshes out this abstract metaphor by suggesting that Millian autonomy could be conceived as the "causal efficacy of one's own second-order choices about the kind of person one wants to become." ${ }^{157}$ Negative liberty is instrumental to Millian autonomy because a choice made under the threat of legal punishment is not expressive of the "agent's authorship." ${ }^{58}$ Importantly, the value of Millian autonomy seems to have a special status for Moore. All the more basic values to which negative liberty is a means are only discussed under the heading of values that can protect minor moral wrongs from criminalization. ${ }^{59}$ But when it comes to the liberty to do serious moral wrongs, Moore exclusively discusses the value of Millian autonomy as the reason which can outweigh the positive reason to criminalize serious moral wrongs. ${ }^{60}$ Thus, if the assumption that infidelity is a serious moral wrong holds true, then whether infidelity ought to be criminalized all-things-considered according to Moore's theory most likely hinges on whether criminalizing infidelity infringes significantly on Millian autonomy. Every criminal law infringes on Millian autonomy to some extent, but not to an equal extent. ${ }^{61}$ To stay with the authorship metaphor, some criminal laws prevent people from putting commas before "that," while other criminal laws prevent the writing of entire chapters or ever using the letter "f."

I shall neither dispute that Millian autonomy is valuable, nor that Millian autonomy can be infringed on by the criminalization of what is morally wrong. Both claims seem intuitive. The question is whether the value of Millian autonomy provides a reason against criminalizing infidelity which outweighs the reason in favour of criminalizing infidelity. This depends on the strength of the reason provided by the value of Millian autonomy, which depends on how valuable

\footnotetext{
${ }^{57}$ Moore, “Liberty's Constraints on What Should Be Made Criminal," 187.

58 Ibid.

59 Ibid., 200-204.

${ }^{60}$ Ibid., 204-206. However, it should be noted that Moore holds that the difference between minor and serious moral wrongs is quantitative, not qualitative (Ibid., 205.)

${ }^{61}$ Moore, "Liberty's Constraints on What Should Be Made Criminal," 205.
} 
Infidelity and the Possibility of a Liberal Legal Moralism - forthcoming in Criminal Law and Philosophy Post-print

The final publication is available at Springer via http://dx.doi.org/10.1007/s11572-015-9370-5.

the negative liberty to engage in infidelity is to Millian autonomy. Moore provides a long list of choices, where Millian autonomy provides an especially weighty reason against criminalization that can outweigh the reason in favour criminalizing even serious wrongs. Of special interest for our present purposes is Moore's emphasis on the necessity of having negative liberty concerning "what forms of friendship, love, and sexual intimacy I should indulge, whether I should marry, [and] who and when I should marry" ${ }^{\prime 2}$ if we are to be the authors of our own lives.

Suppose infidelity is criminalized and $A$ is in a committed romantic relationship with B. Thus, A does not have negative liberty to have sexual relations with C. However, A strongly desires to have sexual relations with $\mathrm{C}$. In order to put the case for holding that infidelity is protected by Millian autonomy as strongly as possible, I assume that A's reason for wanting to have sexual relations with $\mathrm{C}$ is highly relevant for his Millian autonomy. A has made a secondorder choice about who he wants to be, which involves having sexual relations with C. I remain neutral about why exactly A's second-order choice about who he wants to be involves having sexual relations with $C$. Perhaps the sexual gratification is an end in itself, perhaps $A$ is in love with C, perhaps A wants to be someone who is sexually liberated. At any rate, if A cannot act on this second-order choice, this significantly impacts his authorship of his own life.

Now it seems that I have already admitted that the value of Millian autonomy provides a reason against criminalizing infidelity which is certain to outweigh the reason in favour of criminalizing infidelity because it restricts people's negative liberty concerning what forms of sexual intimacy they should indulge in, in a way that significantly impacts their ability to be the authors of their own lives. However, upon closer examination, the weight of the reason against criminalizing infidelity provided by Millian autonomy greatly diminishes. This is so because criminalizing doing $\mathrm{X}$ at time $\mathrm{T}$ in situation $\mathrm{S}$, and criminalizing doing $\mathrm{X}$ at any and all times under any and all circumstances have quite differential impacts on Millian autonomy.

To illustrate this point, consider the example of polygamy. ${ }^{63}$ One action which is uncontroversially protected by Millian autonomy is the right to choose one's own partner, as is also clear from the quote above. ${ }^{64}$ Meanwhile, it is also the case that polygamy is illegal. If $A$ is

\footnotetext{
62 Ibid.

${ }^{63}$ For an insightful discussion of whether polygamy should be criminalized, see Douglas N. Husak, "Polygamy: A Novel Test for a Theory of Criminalization," in Criminalization: The Political Morality of the Criminal Law, ed. R. A. Duff, et al., Criminalization Series 4 (New York, NY: Oxford University, 2014), 213-231.

${ }^{64}$ Moore, Placing Blame, 774; Moore, “Liberty's Constraints on What Should Be Made Criminal," 205.
} 
Infidelity and the Possibility of a Liberal Legal Moralism - forthcoming in Criminal Law and Philosophy Post-print

The final publication is available at Springer via http://dx.doi.org/10.1007/s11572-015-9370-5.

already married to $B$, he cannot legally marry a third party. ${ }^{65}$ If it makes little difference to Millian autonomy whether doing $\mathrm{X}$ is criminal at all times and under all circumstances, or only at some times under some circumstances. Then a law forbidding polygamy is unjust even when the original spouse does not consent to the new marriage ${ }^{66}$ because it severely infringes on Millian autonomy. Call this "non-consensual polygamy." However, it is far from obvious that prohibiting nonconsensual polygamy is unjust, or at least that it is unjust because it severely infringes on Millian autonomy.

Even though respect for Millian autonomy prima facie provides a weighty reason against criminalizing non-consensual polygamy because $A^{\prime} s$ negative liberty to marry who he wants is important to A's Millian autonomy, the weight of this reason is greatly diminished because it is possible for $A$ to divorce the non-consenting spouse $B$ and then marry $C$. Thus, the negative liberty to choose who to marry is only limited under a specific set of circumstancesalready being married-which it is possible for $A$ to change at no unreasonable cost-divorcing $B$. Thus, a ban on polygamy infringes much less on Millian autonomy than it seems at first sight because the constraints it places on the negative liberty to choose who to marry can be easily and legally circumvented. I suggest that whenever the following six conditions are fulfilled the impact on Millian autonomy of criminalizing $X$ in the circumstances, $S_{1}$, at time, $t_{1}$ is greatly reduced:

1) A can and ought to be able to legally do $X$ under $S_{2}$ at $t_{2}$

2) It is not unreasonably difficult for $A$ to move from $S_{1}$ to $S_{2}$.

3) The gap in time between $t_{1}$ and $t_{2}$ is not unreasonable.

4) A can be held responsible for being under $S_{1}$

5) It is not and ought not to be illegal for $A$ to move from $S_{1}$ to $S_{2}$.

6) The negative liberty specifically to do $X$ and $Y$, where $Y$ is only possible in $S_{1}$, is much less important to Millian autonomy than the negative liberty to do $\mathrm{X}$ simpliciter.

To claim that the fulfilment of these six conditions makes no difference to the impact on Millian autonomy of legally preventing $A$ from marrying $C$ at $S_{1}$ is to claim that it is equally limiting on

\footnotetext{
${ }^{65}$ In the U.S., polygamy is illegal in all 50 states. Husak, "Polygamy: A Novel Test for a Theory of Criminalization," 217.

${ }^{66}$ That the original spouse does not know about or consent to the new marriage is, however, not a part of existing laws forbidding polygamy. (Ibid., 218.)
} 
Infidelity and the Possibility of a Liberal Legal Moralism - forthcoming in Criminal Law and Philosophy Post-print

The final publication is available at Springer via http://dx.doi.org/10.1007/s11572-015-9370-5.

Millian autonomy not to be able to act on one's second-order choices about who one wants to be immediately, and not to be able to act on one's second-order choices about who one wants to be at all. But this would seem to make Millian autonomy impossible because many autonomyrelevant ends take significant time to realize.

The question is whether 1) through 6) are fulfilled by the action of having sexual relations with somebody other than one's current romantic partner. If they are, then restricting the negative liberty to commit infidelity by criminalizing infidelity infringes much less on Millian autonomy than may be thought because the impact on the negative liberty to choose who to have sexual relations with, which is of particular importance to Millian autonomy, is diminished. 1) through 4) seems unproblematically fulfilled, while both 5) and 6) merit closer discussion. As for 1), A can bring herself into a situation where she can legally have sex with $C$ even though infidelity is criminalized. Namely, A can end the romantic relationship with B. As for 2) and 3), it is neither unreasonably difficult, nor unreasonably time-consuming for $A$ to end the relationship with $B$, and thus bring herself into a situation, where she can have sex with $C$. After all the termination of a relationship is an act entirely within A's own power and effective immediately. Regarding 4), barring something like a forced marriage (a crime in its own right), A can be held responsible for being in a relationship with $B$.

For 5) to be fulfilled, it must be the case that it is not and ought not to be illegal for $A$ to end the relationship with B. Here, one might claim that leaving one's romantic partner ought not to be illegal, because it is not morally wrong. However, many of the suggested reasons infidelity is morally wrong applies equally to leaving one's long-time romantic partner. Terminating a romantic relationship will also often involve knowably and foreseeably deeply hurting someone else, and the breach of promises. Just think of all the things married couples promise each other in their wedding wows. However, prohibiting people from leaving their romantic partners would itself greatly infringe on their Millian autonomy, and would therefore be unjust. Such a prohibition would greatly reduce people's authorship over their own lives in the central respect of forcing them to maintain certain romantic attachments. For this reason, I take 5) to be fulfilled, since it is 
Infidelity and the Possibility of a Liberal Legal Moralism - forthcoming in Criminal Law and Philosophy

Post-print

The final publication is available at Springer via http://dx.doi.org/10.1007/s11572-015-9370-5.

possible for A to bring herself into a situation where it is legal for her to have sexual relations with C by leaving $B$, and leaving $B$ ought not to be illegal. ${ }^{67}$

For 6) to be fulfilled, it must be the case that restricting the negative liberty to both have sexual relations with somebody other than one's current romantic partner while still remaining in a relationship with this partner does not infringe on Millian autonomy to any great extent. But why should it? To be sure, it might be in A's interest to both have sexual relations with $C$ and remain in a relationship with $B$, but surely this cannot be enough to show that it is especially important to Millian autonomy. Furthermore, if A's Millian autonomy is greatly infringed upon if he does not have the negative liberty to stand in a certain relation to $B$, the romantic relationship, while doing something that violates B's conditions for consenting to standing in this relationship to A, being unfaithful, ${ }^{68}$ where is the respect for B's autonomy? When A deliberately deceives B about the reasons on which B bases her major self-defining decisions, A actively hinders B in being an author of her own life. I conclude that the negative liberty to simultaneously be in a romantic relationship and have sexual relations with a third party is not very important to Millian autonomy. It is therefore unlikely that criminalizing infidelity infringes on Millian autonomy to such a degree that the reason against criminalizing infidelity provided by the value of Millian autonomy outweighs the reason in favour of criminalizing infidelity. This is fully compatible with believing that the negative liberty to choose one's own sexual partner is highly relevant to Millian autonomy.

\section{Costs of Enforcement}

I now discuss whether the costs of enforcing a criminal ban on infidelity outweigh the reason in favour of criminalizing infidelity. The argument that infidelity should not be criminalized because of the costs of enforcement takes the form of a dilemma: either a law is effectively enforced or it is not. Both effectively enforcing and not effectively enforcing the law must be problematic. If

\footnotetext{
${ }^{67}$ This argument entails that in countries where divorce is illegal an argument for the legality of infidelity could be made on the grounds of Millian autonomy. I here discuss whether Millian autonomy protects infidelity from criminalization in an ideally just society, and in such a society divorce would be legal.

${ }^{68}$ Recall that infidelity was the most common cause of divorce across 160 different cultures. (Shackelford, LeBlanc, and Drass, "Emotional Reactions to Infidelity.") This underscores that being unfaithful is often seen as a violation of the deceived party's conditions for being in the romantic relationship.
} 
Infidelity and the Possibility of a Liberal Legal Moralism - forthcoming in Criminal Law and Philosophy Post-print

The final publication is available at Springer via http://dx.doi.org/10.1007/s11572-015-9370-5.

either is not problematic, then the costs of enforcement provide no reason against criminalizing infidelity. According to Moore, effectively enforcing a law can be problematic because of the direct economic costs of enforcing the law, ${ }^{69}$ and because of costs in morally valuable privacy. ${ }^{70}$ Underenforcing a law can be problematic because it creates a crime tariff, causes disrespect for the law in general, creates potential for blackmail, and creates potential for discriminatory enforcement. ${ }^{71}$ If the cost of enforcement is a sufficient reason against criminalizing infidelity, we get the following dilemma:

Either

A) The criminal ban on infidelity is effectively enforced,

Or

B) The criminal ban on infidelity is not effectively enforced.

If A), then:

C) The direct economic costs of enforcing the law, the decrease in morally valuable privacy, or some combination of both outweigh the reason in favour of criminalizing infidelity.

If $B)$, then:

D) The creation of a crime tariff, the resulting disrespect for the law, the creation of a potential for blackmail, the potential for discriminatory enforcement, or some combination of those outweigh the reason in favour of criminalizing infidelity.

I tackle the first horn of the dilemma and argue that A) does not imply C). Effectively enforcing a criminal ban on infidelity will not result in direct economic costs or privacy costs that outweigh the reason in favour of criminalizing infidelity. Because showing that one horn of the dilemma is not actually problematic is enough to reject the dilemma. I do not discuss whether B) implies D), though I believe a much better case can be made for this claim. Especially, it seems to me that traditionally legislation against infidelity has been discriminatorily enforced by disproportionality targeting female offenders.

\footnotetext{
${ }^{69}$ Moore, Placing Blame, 663.

${ }^{70}$ Ibid., 664.

${ }^{71}$ Ibid. See also Moore, “Liberty's Constraints on What Should Be Made Criminal," 203.
} 
Infidelity and the Possibility of a Liberal Legal Moralism - forthcoming in Criminal Law and Philosophy Post-print

The final publication is available at Springer via http://dx.doi.org/10.1007/s11572-015-9370-5.

\section{Direct Economic Cost}

Direct economic costs cannot be directly morally relevant. Economic resources only have moral value insofar as they are a means of achieving some morally valuable goals. However, direct economic costs are indirectly morally relevant. The achievement of most morally valuable goals requires the expenditure of some resources. Effectively enforcing a criminal ban on infidelity will have some economic costs. For direct economic costs to provide a reason against criminalizing infidelity which outweighs the reason in favour of criminalizing infidelity, it must be true that if we spend the resources required to effectively enforce a criminal ban on infidelity, it is impossible to realize a set of goals that are jointly more morally valuable to realize than effectively enforcing a criminal ban on infidelity, and which it would have been possible to realize if resources had not been spent on enforcing a criminal ban on infidelity. Call these goals "V."

Most can probably name some goals which are more morally valuable to realize than punishing adulterers, and which cannot be realized while also enforcing a criminal ban on infidelity assuming that the revenues and the resources spent on other things than enforcing a criminal ban on infidelity and realizing $V$ are held constant. However, this assumption is unwarranted. It needs to be argued that the costs of realizing $V$ should be covered by not enforcing a criminal ban on infidelity instead of cutting back on other expenses or finding new sources of revenue. Thus, these two further propositions both need to be true:

Available Expenditure: The resources spent on achieving less morally valuable goals than enforcing a criminal ban on infidelity are insufficient to cover the expenses of effectively enforcing a criminal ban on infidelity and simultaneously realizing $\mathrm{V}$.

Available Revenue: The additional resources that are morally permissible to access are insufficient to cover the expenses of effectively enforcing a criminal ban on infidelity and simultaneously realizing $\mathrm{V}$. 
Infidelity and the Possibility of a Liberal Legal Moralism - forthcoming in Criminal Law and Philosophy Post-print

The final publication is available at Springer via http://dx.doi.org/10.1007/s11572-015-9370-5.

If Available Expenditure is false, then the appropriate response to the problem of simultaneously enforcing a criminal ban on infidelity and realizing $V$ is to cut expenditure on goals that are less morally valuable than enforcing a criminal ban on infidelity. If Available Revenue is false, then the appropriate response to the problem of simultaneously enforcing a criminal ban on infidelity and realizing $\mathrm{V}$ is to increase revenue. It also must be true that combining the two measures are jointly insufficient to cover the costs of effectively enforcing a criminal ban on infidelity and simultaneously realizing $\mathrm{V}$.

Whether Available Expenditure and Available Revenue are true are ultimately empirical questions, which cannot be answered conclusively here. However, I think we have reason to doubt that they are true. In order for Available Expenditure to be true, the resources required to effectively enforce a criminal ban on infidelity must exceed the resources currently spent in pursuit of less morally valuable goals. Moore himself explicitly mentions that the use of recreational drugs should not be criminal, ${ }^{72}$ making the 41.3 billon USD spend annually on enforcing laws against recreational drugs an expenditure with no (or negative) moral value, ${ }^{73}$ and thus less morally valuable than enforcing a criminal ban on infidelity. Decriminalizing recreational drugs would thus make a large amount of resources available for enforcing a criminal ban on infidelity, though maybe the 41.3 billion annually are not enough. But, there may be other pointless expenditures. Though any particular example may be controversial, I think most people will probably be able to mention some. In order for Available Revenue to be true, it needs to be argued that taxes could not permissibly be raised in order to afford both the enforcement of a criminal ban on infidelity and realizing $\mathrm{V}$. It might be difficult to argue that raising taxes is impermissible in order to achieve a goal, which, according to Moore's theory, it is the proper business of the state to pursue: punishing the immoral act of infidelity. One possible line of argument for the truth of Available Revenue could be that currently, or at some point, falling short of covering the costs of enforcing a criminal ban on infidelity, additional revenue cannot be accessed, because the negative externalities of raising the tax rate (e.g., disincentive to work) would decrease societal wealth such that an increase in the tax rate would actually cause a decrease in the overall tax-income. I cannot pursue this further here.

\footnotetext{
${ }^{72}$ Moore, Placing Blame, 661, 778ff.

73 Jeffrey A. Miron and Katherine Waldock, The Budgetary Impact of Ending Drug Prohibition (Cato Institute, 2010), http://www.cato.org/sites/cato.org/files/pubs/pdf/DrugProhibitionWP.pdf.
} 
Infidelity and the Possibility of a Liberal Legal Moralism - forthcoming in Criminal Law and Philosophy Post-print

The final publication is available at Springer via http://dx.doi.org/10.1007/s11572-015-9370-5.

Ultimately, it is an empirical question whether the direct economic cost of effectively enforcing a criminal ban on infidelity provides a reason against criminalizing infidelity which outweighs the reason in favour of criminalization. However, I have shown that in order for this to be so some further controversial propositions must be true. At the very least, this raises reasonable doubt about whether infidelity should not be criminalized because of the direct economic costs of enforcing such a law.

\section{Privacy Costs}

I now discuss the privacy costs of enforcing a criminal ban on infidelity. It should be noted that in his remarks on privacy Moore only suggests that enforcement of a law can violate privacy. ${ }^{74}$ Thus, only this sense of privacy is discussed and I shall not discuss privacy in the stronger senses where it can be violated by the mere existence of a law. ${ }^{75}$ Moore illustrates privacy-violating enforcement of the law, with the following example:

At one point in time, the federal park rangers in Yosemite National Park sought to enforce the legislation against homosexual behaviour by placing peep-holes over the stalls in the men's bathroom, so that they could see into each of such stalls and check for illegal behaviour. This kind of evidence gathering is costly to a society, both in terms of the privacy, and in terms of the dignity of all concerned. ${ }^{76}$

The question now is whether enforcement of a criminal ban on infidelity would have to include privacy-violating measures in order to be effective. After all, there is some likeness with the example Moore provides. The acts of infidelity that interest us here are sexual in nature, and they will typically be carried out in private. Installing peep-holes in the bedrooms of all citizens could be a very effective way of enforcing a criminal ban on infidelity. However, effective enforcement of a law is not perfect enforcement. If it is a requirement of effectively enforcing a law that all who break it are caught, then no laws are effectively enforced. Furthermore, effective enforcement is

\footnotetext{
${ }^{74}$ Moore, Placing Blame, 664.

${ }^{75}$ For such a conception of privacy (though one Moore cannot appeal to since it is incompatible with his legal moralism), see Duff, Answering for Crime.

${ }^{76}$ Moore, Placing Blame, 664.
} 
Infidelity and the Possibility of a Liberal Legal Moralism - forthcoming in Criminal Law and Philosophy Post-print

The final publication is available at Springer via http://dx.doi.org/10.1007/s11572-015-9370-5.

not total enforcement; a law might be effectively enforced, even though the police do not literally do everything they could to enforce it. To my knowledge, there is no police agent carrying out surveillance of my living room in case I might commit murder there. Thus, the fact that installing peep-holes could be effective does not mean it is necessary to install peep-holes in order to enforce a criminal ban on infidelity.

Unfortunately, Moore does not spell out when enforcing a law violates privacy; he only gives us the quoted example. So I turn to W. A. Parent's account of the right to privacy. ${ }^{77}$ Parent's account has two advantages. First, it is explicitly concerned with the ways in which enforcing the law might violate privacy, which is similar to Moore's focus. Second, one of the central examples is the same one used by Moore-spying on public bathrooms in order to enforce legislation against homosexuality. ${ }^{78}$ Therefore, I hope her conception of a right to privacy is close to the one Moore has in mind. Parent lists five requirements that enforcement of any law must fulfil in order to respect privacy:

A. The need requirement. There must be a valid or legitimate need for invading privacy. ${ }^{[79]}$

B. The probable cause requirement. There must be probable cause to believe that the information sought is relevant to the justifying need. And there must be probable cause to believe that this information (and not some other irrelevant information) can be obtained by the techniques recommended.

C. The alternative means requirement. There mustn't be any alternative, less intrusive means available for obtaining the desired information.

$D$. The warrant requirement. An impartial judicial officer issue a warrant describing the place to be searched and the information sought ...

E. The security requirement. There must be restrictions on cognitive access to the information during the times of its acquisition, disclosure, and storage, so that only persons entitled to know the facts have them. ${ }^{80}$

\footnotetext{
${ }_{77}^{7}$ W. A. Parent, “A New Definition of Privacy for the Law," Law and Philosophy 2, no. 3 (December 1983): 305-338.

78 Ibid., 310.

${ }^{79}$ Presumably, privacy can be invaded without being violated, the former being compatible with respecting privacy while the latter is not.

${ }^{80}$ Quoted from Parent, “A New Definition of Privacy for the Law," 311.
} 
Infidelity and the Possibility of a Liberal Legal Moralism - forthcoming in Criminal Law and Philosophy Post-print

The final publication is available at Springer via http://dx.doi.org/10.1007/s11572-015-9370-5.

Only the second requirement can be problematic for a law criminalizing infidelity in general, as opposed to ruling out particular means of enforcement. Presumably, the legitimate need for invading privacy is punishing those who commit the moral wrong of infidelity, and arguing that criminalizing infidelity violates A. can only be done by either rejecting Moore's theory or denying that infidelity is morally wrong. Enforcing a criminal ban on infidelity can only violate $\mathrm{C}$. if there is another, less intrusive way to enforce the criminal ban, which means there is no problem for a law criminalizing infidelity in general. While it is surely possible to point to violations of D. and E., it is hard to see that there should be some ways of enforcing a criminal ban on infidelity that could be ruled out in principle, because they violated $\mathrm{D}$. and $\mathrm{E}$.

We are left with B., the probable cause requirement. Appropriately, it is this requirement that is flagrantly violated by the Yosemite National Park rangers when they install peep-holes above the bathroom-stalls. Installing the peep-holes because someone might engage in homosexual activities in the stalls presumably enables park rangers to obtain lots of irrelevant information in connection with people using the bathroom stalls for their intended purpose. It is conceivable that there are laws for which every effective means of enforcement will have to violate the probable cause requirement. The question is whether a criminal ban on infidelity would be such a law.

One reason for thinking that a criminal ban on infidelity can be effectively enforced without violating the probable cause requirement is that infidelity has a victim, a non-consenting person who is actually wronged, namely the deceived partner. The informed suspicions of the deceived partner might help give the police probable cause for knowing when and where infidelity occurs, enabling enforcement, without acquiring sensitive and irrelevant information, and respecting the probable cause requirement. That the informed suspicions of the deceived partner can give the police probable cause may be particularly clear when the deceived partner lives with the adulterer. First, there is the possibility of catching the unfaithful partner red-handed. Second, the deceived partner is in a good position to form true beliefs about the unfaithful partner's infidelity on the basis of otherwise inexplicable patterns of behaviour (i.e., a sudden systematic pattern of the unfaithful partner "working late"), and intimate knowledge of the romantic partner. 
Infidelity and the Possibility of a Liberal Legal Moralism - forthcoming in Criminal Law and Philosophy Post-print

The final publication is available at Springer via http://dx.doi.org/10.1007/s11572-015-9370-5.

Admittedly, a society where spouses report one another to the police for infidelity sounds potentially morally problematic (and yet, it hardly seems problematic that one spouse can report another spouse to the police for domestic abuse), but it is far from clear that it is morally problematic because it violates privacy in the sense mentioned by Moore. For one thing, this worry about the effects of a criminal ban on infidelity seems unconnected to the enforcement of the criminal ban. The worry would arise whether the ban was effectively enforced or not, since even a very ineffective law against infidelity would allow one partner to report another for infidelity. It cannot be this worry Moore has in mind when he writes about privacy, since he seems only to worry (explicitly) about whether enforcement can violate privacy.

The presence of a victim of infidelity makes it realistic that a criminal ban on infidelity could be effectively enforced without violating the probable cause requirement, and, thus, without violating privacy in the sense mentioned by Moore. ${ }^{81}$ If I am right in this, the morally relevant costs of enforcement mentioned by Moore-direct or indirect-do not provide a reason against criminalizing infidelity, which outweighs the reason in favour of criminalizing infidelity founded on the moral wrongfulness of infidelity. I have now discussed all the reasons not to criminalize what is morally wrong mentioned by Moore, without finding any reason which reason against criminalizing infidelity which were sufficient to outweigh the reason in favour of criminalizing infidelity.

\section{Concluding Remarks: The Possibility of a Liberal Legal Moralism}

I have argued that, if we accept Moore's legal moralism, there is a positive reason to criminalize infidelity, and that none of the reasons against criminalizing what is morally wrong mentioned by Moore can outweigh the positive reason. Before ending, I would like to comment on what has not been shown, and the repercussions for the possibility of liberal legal moralism.

First, one way to deny the conclusion is to deny that infidelity is (more than trivially) morally wrong. This seems to me deeply implausible, but has not been conclusively argued to be false here. Secondly, while I argued that Moore has not provided any reason against criminalizing infidelity that can outweigh the positive reason to criminalize it provided by the moral

\footnotetext{
${ }^{81}$ This is not to say that it may not violate privacy on some conceptions of privacy, which Moore has not appealed to.
} 
Infidelity and the Possibility of a Liberal Legal Moralism - forthcoming in Criminal Law and Philosophy Post-print

The final publication is available at Springer via http://dx.doi.org/10.1007/s11572-015-9370-5.

wrongfulness of it, I have not been argued that Moore's theory prevents him from giving such a reason. Maybe Moore could appeal to some hitherto unmentioned value which enables him to deny that his theory implies that infidelity should be criminalized. The best candidate for this is probably some stronger conception of privacy. Third, I have not demonstrated that the direct costs of effectively enforcing a criminal ban on infidelity could not provide a reason against criminalizing infidelity which outweighed the reason in favour of criminalizing infidelity. However, I have argued that the additional propositions that must be true for this to be the case are quite radical. Fourth, since all the values provided some reason against criminalizing infidelity, it remains possible that they jointly provide a reason which could outweigh the positive reason to criminalize infidelity. This seems to me unlikely. This is so partly because I argued that if infidelity is wrong it is a quite serious moral wrong, which means the reason in favour of criminalizing infidelity is quite strong, and partly since Millian autonomy should probably have provided most of the strength to a set of reasons which jointly outweighs the reason in favour of criminalizing infidelity, because the value of Millian autonomy has the potential to provide a much stronger reason against criminalizing what is morally wrong than the reason provided by the other values. However, the impact of criminalizing infidelity on Millian autonomy is rather small. Fifth, while I have argued that Moore's legal moralism has the implication that infidelity should be criminalized, I have not argued that this implication is implausible. Moore could just accept that infidelity should be criminalized, though this would no doubt be a controversial position.

However, even if Moore accepts that infidelity should be criminalized, there is a problem. Moore emphatically stresses that his theory of the proper legislative aim is a liberal legal moralism ${ }^{82}$ that is "quite liberal-in-outcome, if not liberal-in-form. ${ }^{83}$ But, if criminalizing infidelity is justified according to Moore's legal moralism, this is false. Criminalizing infidelity is anything but a quite liberal outcome.

Whether Moore's legal moralism is liberal is important. An important mode of argument in this debate between liberalism and legal moralism is to criticize the other theory by showing that it has counter-intuitive implications. For instance, legal moralism has historically been criticized for permitting the criminalization of homosexuality, ${ }^{84}$ while liberalism has been

\footnotetext{
${ }^{82}$ Moore, Placing Blame, 661ff.

83 lbid., 661.

${ }^{84}$ H. L. A. Hart, Law, Liberty, and Morality (Stanford, California: Stanford University, 1963).
} 
Infidelity and the Possibility of a Liberal Legal Moralism - forthcoming in Criminal Law and Philosophy

Post-print

The final publication is available at Springer via http://dx.doi.org/10.1007/s11572-015-9370-5.

criticized for disallowing the criminalization of public gladiatorial combat to the death, as long as both gladiators are consenting adults. ${ }^{85}$ Elements of this mode of argument are present in Moore when he notes that liberals cannot justify criminalizing cruelty to animals or the mutilation dead bodies, which Moore seems to view as problems for liberalism. ${ }^{86}$ Making legal moralism more liberal-in-outcome strengthens it by making it less vulnerable to the liberal attack that it has counter-intuitive legislative implications, since the implications do not differ greatly from the implications of liberalism. This is a powerful tool in the arsenal of the legal moralist.

Moore tries to make his legal moralism liberal in two ways. First, he limits the scope of our moral obligations. ${ }^{87}$ Second, he presents a battery of reasons against criminalization, which can potentially outweigh the reason to legally enforce morality. ${ }^{88}$ This is to a large extent a great success. It is largely these two moves that make Moore's legal moralism the most compelling to date. However, showing that Moore's legal moralism implies that infidelity should be criminalized highlights the limitations of how liberal-in-outcome legal moralism can become. There are some acts that are morally wrong, which there is no weighty reason against criminalizing, but which are still undeniably controversial and manifestly illiberal to criminalize. Infidelity is one such act. Perhaps there is some reason against criminalizing infidelity that has been overlooked, but for now it seems that anyone who wishes to argue that infidelity should not be criminalized must argue that there is no positive reason to criminalize infidelity even though it is morally wrong; that is one must reject legal moralism.

If I am right about this, the failure of Moore's legal moralism to be quite liberal-inoutcome raises questions about the possibility of liberal legal moralism. Of course, Moore's theory is not the only elaborate version of legal moralism. But other elaborate defences, such as those put forth by James Fitzjames Stephens, ${ }^{89}$ Patrick Devlin, ${ }^{90}$ and Robert P. George, ${ }^{91}$ have tended to be based on a conservative moral outlook, and have happily admitted their manifestly illiberal implications for legislation. Nor is Moore's theory the only defence of a liberal legal moralism.

\footnotetext{
${ }^{85}$ Irving Kristol, “Pornography, Obscenity and the Case for Censorship," The New York Times Magazine, March 28, 1971, http://www.rense.com/general87/obscenity.htm.

${ }^{86}$ Moore, Placing Blame, 646-647.

${ }^{87}$ Ibid., 662.

88 Ibid., Chapter 18.

${ }^{89}$ Stephen, Liberty, Equality, Fraternity.

${ }^{90}$ Devlin, The Enforcement of Morals.

${ }^{91}$ George, Making Men Moral.
} 
Infidelity and the Possibility of a Liberal Legal Moralism - forthcoming in Criminal Law and Philosophy Post-print

The final publication is available at Springer via http://dx.doi.org/10.1007/s11572-015-9370-5.

Richard Arneson ${ }^{92}$ and especially Gerald Dworkin ${ }^{93}$ can both be read as defending distinctively liberal versions. But, while their contributions to this debate are certainly interesting, they are nowhere near as elaborate as Moore's contribution. In this sense, Moore's legal moralism is unique in that it is both extremely elaborate, and aims to be quite liberal-in-outcome. As we have seen, Moore's legal moralism falls short of this goal. Maybe another legal moralist could provide an (even) more complete account of the relevant reasons against criminalizing what is morally wrong, which would result in a legal moralism that is genuinely quite liberal-in-outcome. However, in light of the elaborateness and sophistication of Moore's legal moralism and its commitment to being quite liberal-in-outcome, it might be doubted whether such a thing as liberal legal moralism is even possible. Maybe the "illiberal form" of legal moralism will have significant consequences for its legislative implications on any plausible conception of the scope of our moral obligations, and the relevant reasons against criminalization. The implications of Moore's legal moralism for the criminalization of infidelity, and its consequent failure as a liberal legal moralism, tentatively support this proposition. Of course, one could just embrace the criminalization of infidelity and believe that legal moralism is none the worse for being not quite liberal-in-outcome. However, that too is an interesting conclusion.

\footnotetext{
${ }^{92}$ Arneson, "The Enforcement of Morals Revisited."

${ }^{93}$ Dworkin, "Devlin Was Right."
} 